\title{
RELATIONSHIP BETWEEN THE GANGLION CELL LAYER OF THE RETINA AND THE OPTIC NERVE IN THE RAT*
}

\author{
BY \\ J. T. EAYRS \\ From the Department of Anatomy, University of Birmingham
}

EXPERIMENTAL studies of the changes which take place in the retina when the optic nerve is divided have not yielded consistent results. Birch-Hirschfeld (1900) was the first to report that chromatolysis occurs in the ganglion cells, and a number of authors have described subsequent degenerative changes in the optic nerve fibres themselves. Secondary degeneration of the axons is said to be restricted to the distal segment, the retrograde changes in the axons of the proximal segment being confined to the traumatic phase (Ramón y Cajal, 1928). According to Tello (1907), such degeneration may involve the intraretinal fibres if the nerve is cut close to the eyeball, and is usually followed by regenerative changes.

James (1933), who investigated the progress of retrograde degeneration in the rabbit retina, confirmed that chromatolysis occurs soon after the optic nerve is cut, but found that this is succeeded by complete dissolution of most of the ganglion cells. On the other hand, Leinfelder (1938) showed that the degeneration which succeeded optic nerve section in the cat was incomplete, and that, while there was a diminution of the number of ganglion cells left in the retina, many normal cells remained. A more recent study by Mantz and Klein $(1951 \mathrm{a}, \mathrm{b})$, which appeared after the work reported in this paper had been completed, showed that, in the retina of the rat also, many seemingly healthy ganglion cells remain after intracranial section of the optic nerve, although there is a reduction in the thickness of the layer of optic nerve fibres and of the internal plexiform layer.

The effects of interrupting the optic nerve in immature animals have not previously been studied. Accordingly, the investigation reported here was carried out in the hope that it might resolve some of the different views found in the literature, and at the same time provide information about the effect on retinal maturation of crushing the optic nerve.

\section{Materials and Methods}

Thirteen infant rats aged between 5 and 7 days were used. Under ether anaesthesia, a small incision was made in the skin just below the temporal canthus, and through this incision the fascia of the eyeball was pierced with a discission knife. The gap thus made was gently widened to expose the back of the eyeball. A pair of curved forceps was then passed behind the eyeball and compressed for a few seconds on the tissues surrounding the optic nerve. A mock operation was performed on the opposite side.

- Received for publication December 27, 1951. 
At the age of about 65-70 days the animals were killed with chloroform vapour, and their brains removed to permit examination of the optic nerves. The two eyeballs were then fixed, either in 10 per cent. formol saline or in 90 per cent. alcohol, and embedded in paraffin wax. Representative sections were cut at $10 \mu$ passing sagittally through the optic disk. Adjacent sections were stained with Van Gieson and cresyl violet; by a modification the silver chloride method for nerve fibres (Romanes, 1950); and with methyl green-pyronin as a means of distinguishing the presence of nucleic acid polymers in nucleus and cytoplasm. Both eyeballs of each rat were treated identically throughout.

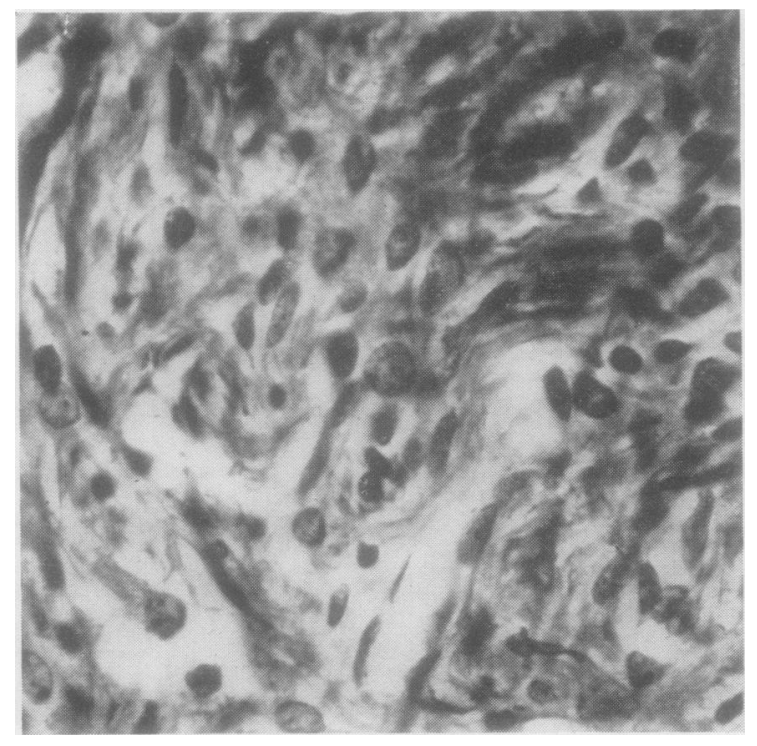

FIG. 1.-Optic nerve from operated side of rat aged 70 days (silver impregnation. $\times 650$ ). All trace of orientation has disappeared and no nerve fibres can be seen.

FIG. 2.-Normal optic nerve of same rat as in Fig. 1 (silver impregnation. $\times 650$ ). The nerve fibres are orientated into well-marked fasciculi separated by glial and connective tissue.

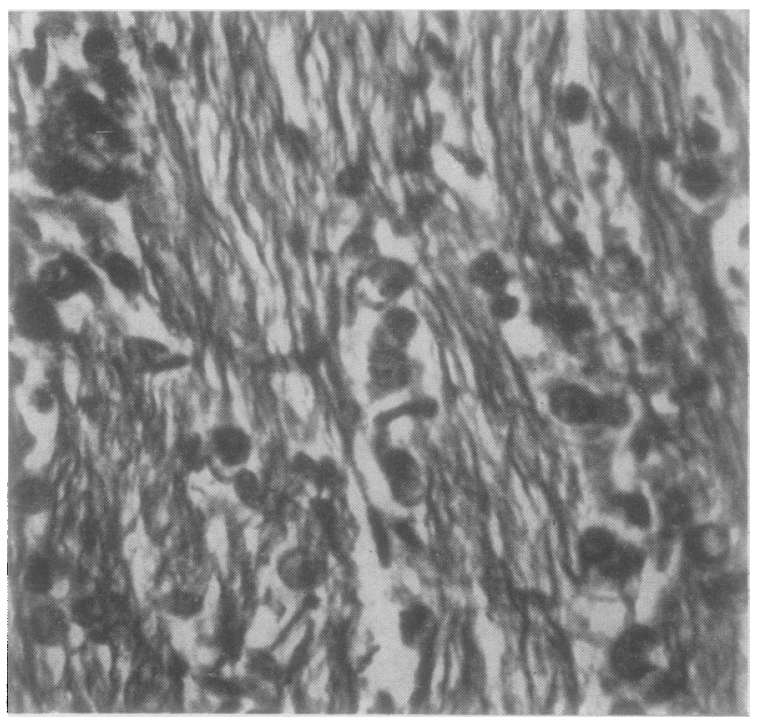




\section{Results}

Degeneration of Optic Nerve.-The portion of the optic nerve distal to the site of crushing had in all instances completely degenerated. The intracranial course of the nerve was sometimes marked by a fine fibrous strand which contained no recognizable nervous tissue, but often no trace of the nerve remained. The site of emergence of the proximal stump from the eyeball was marked by a small papilla. Histological examination showed this to consist mainly of fibroblasts and organizing collagenous connective tissue (Fig. 1), contrasting markedly with the appearance of the normal nerve (Fig. 2).

Growth of Eyeball.-To all outward appearance, the eyeballs on both operated and control sides were indistinguishable at autopsy. On weighing, however, those with the optic nerves crushed were consistently about 10 per cent. lighter than those with intact optic nerves (see Table).

TABLE

EFFECT OF CRUSHING THE OPTIC NERVE IN INFANCY ON THE GROWTH OF THE EYEBALL AND ON THE NUMBER OF GANGLION CELLS IN THE RETINA OF THE RAT

\begin{tabular}{c|c|c|c|c|c|c}
\hline Variate & $\begin{array}{c}\text { Number } \\
\text { of } \\
\text { Eyeballs }\end{array}$ & $\begin{array}{c}\text { Control } \\
\text { Side }\end{array}$ & $\begin{array}{c}\text { Operated } \\
\text { Side }\end{array}$ & Difference & $t$ & $P$ \\
\hline $\begin{array}{c}\text { Mean weight of eyeballs at } \\
\text { autopsy (about 65 days old) }\end{array}$ & 12 & $96.5 \pm 1.80$ & $86.1 \pm 4.16$ & $10.4 \pm 4.52$ & 2.301 & $0.05-0.02$ \\
$\begin{array}{c}- \text { mg. } \pm \text { standard error of } \\
\text { mean } \\
\text { Mean number of ganglion cells } \\
\text { in representative sections of } \\
\text { retina passing through optic } \\
\text { disc } \pm \text { standard error of mean }\end{array}$ & 14 & $428 \pm 28.3$ & $194 \pm 19.5$ & $234 \pm 34.4$ & 6.803 & $<0.001$ \\
\hline
\end{tabular}

Maturation of Retina.-Notwithstanding the slightly reduced growth of the eyeball, crushing the optic nerve did not interfere with the differentiation of the outer layers of the retina. Histologically the retinal structure at the time of operation accorded with the description given by Detwiler (1932) for the 5-day-old rat, the layers of bipolar and visual cells being poorly differentiated. The ganglion cell layer, however, was well marked, and consisted of a row of large and rather crowded cells separated from the innermost row of bipolar cells by a narrow internal plexiform layer. This layer decreased progressively in thickness from the optic disk towards the ora serrata. The layer of optic nerve fibres was relatively thicker than in the adult retina.

Cytologically, the methyl green-pyronin method showed that the ganglion cells contain abundant pyronin-staining material, presumably Nissl substance, most of which was concentrated adjacent to the internal plexiform layer and was frequently seen in processes which extended into that layer. The cells destined to form the bipolar layer could be distinguished by the presence of a pyronin-staining constituent in the cytoplasm, which was more scanty in the outermost cells than in those adjacent to the inner plexiform layer. Material which stained with pyronin was also seen in the optic nerve and in the sclera, but not in the presumptive visual cells. In the adult retina, such material was confined to the cytoplasm of cells in the ganglion and bipolar layers, and to the inner segments of the rods. 
Notwithstanding the fact that the optic nerve was crushed at a time when the retina was so little differentiated, the appearance of the outer layers of the experimental retinae (Fig. 3) was not noticeably different from that of the control tissues (Fig. 4).

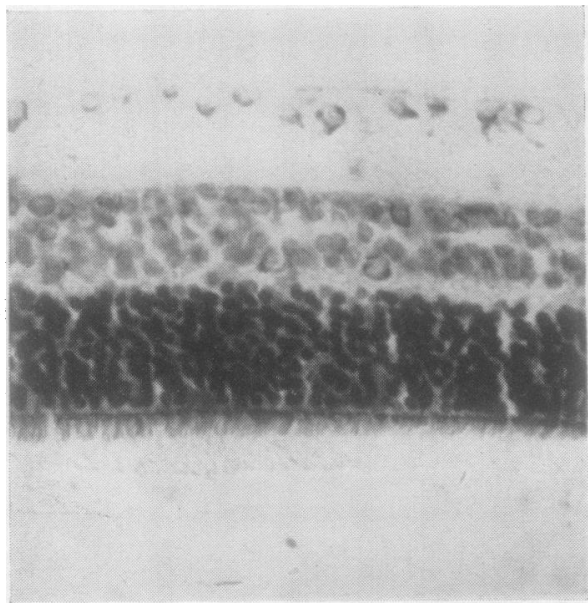

Fig. 3.-Retina of rat aged 70 days on the operated' side (methyl green-pyronin stain. $\times 425)$. The appearance of the ganglion cell nuclei is like that of many of those in the normal retina, and the Nissl substance is similarly distributed although scantier.

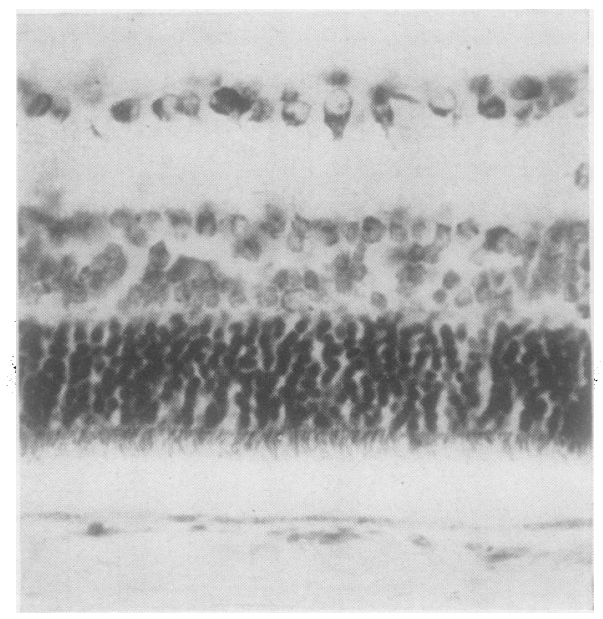

Fig. 4.-Normal retina of same rat as in Fig. 3 (methyl green-pyronin stain. $\times$ 425.) The Nissl substance is prominently stained and surrounds a clear nucleus. No optic nerve fibre layer is visible since the section does not pass through a fasciculus (see Fig. 5).

Degeneration of Retina.-There was a considerable reduction in the number of cells in the ganglion cell layer of the retina on the operated side. A count of these cells, made in representative sagittal sections passing through the optic disk (cresyl violet stain), showed that rather more than half had disappeared (see Table). All the large ganglion cells with coarse Nissl granules and many of those of medium size were no longer present. Those that remained consisted of small cells containing fine pyronin-staining granules interspersed with medium-sized cells, some of which contributed well-marked processes to the internal plexiform layer. Comparison of the methyl green-pyronin stained sections of the experimental and control retinae gave the impression that the destruction of the optic nerve had caused a severe depletion of Nissl substance. This depletion, however, seemed as likely to be due to the elimination of the larger cells as to a uniform reduction in all, for many cells resembling those found in the experimental retinae could be seen in the control tissues.

There were no long-coursing axons in the layer of optic nerve fibres of the experimental tissues. No regenerating axons were seen anywhere in the retina. The presence of short axons could neither be established with certainty nor disproved owing to the difficulty of distinguishing these in sagittal sections from the internal limiting membrane and the occasionally adherent fragments of the hyaloid membrane. Figs 5 and 6 , however, in addition to illustrating the disappearance of all optic nerve fibres in the retina, show the multipolar nature of the remaining cells, suggesting that their dendrites still participate in the synaptic network of the inner plexiform layer. 


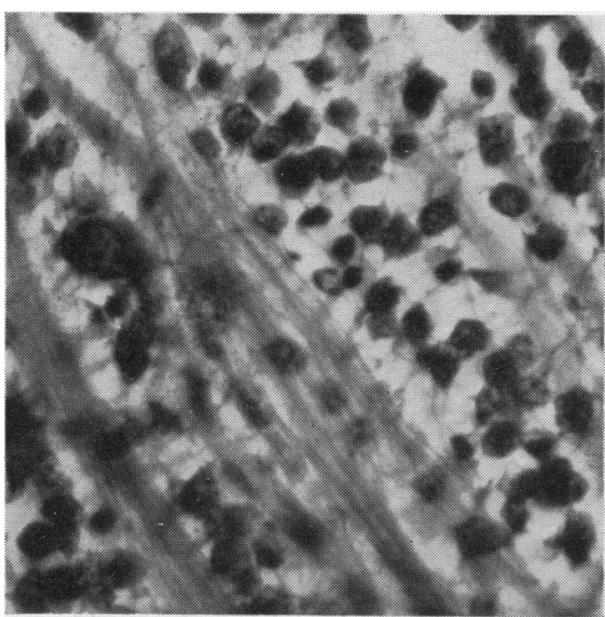

FIG. 5.-Normal retina of rat aged 70 days (silver impregnation. $\times 540$ ). The section passes tangentially through the ganglion cell and nerve fibre layers. Note the fasciculated arrangement of the optic nerve fibres which traverse the plane of section. Some of the fine processes of the ganglion cells can also be seen. The large ganglion cell to the left is of the type which disappears completely after destruction of the optic nerve.



FIG. 6.- Retina on operated side from same rat as in Fig. 5 (silver impregnation. $\times 540$ ). The plane of section is similar to that of Fig. 5 . Note the complete absence of optic nerve fibres, although the processes of some of the ganglion cells can clearly be seen.

\section{Discussion}

The observations here reported show that many cells remain in the ganglion layer long after complete destruction of the optic nerve, thus confirming the findings of Mantz and Klein (1951b). The almost total disappearance of ganglion cells reported by James (1933) in the rabbit does not therefore occur in the rat, although in both species it is the large ganglion cells which appear most sensitive to trauma. In the cat, too, some ganglion cells remain after optic nerve section (Leinfelder, 1938), but in contrast to rodents the large ganglion cells in this animal appear less affected than the small ones. Leinfelder also reported that the degeneration of ganglion cells was more severe than that of the optic nerve fibres, an observation quite out of keeping with the present results, which show the total disappearance of fibres both in the optic nerve itself and in the fibre layer of the retina. This divergence cannot be attributed solely to the immaturity of the retina at the time of operation, for Mantz and Klein (1951b), who used adult rats, likewise reported a disappearance of optic nerve fibres-although they based their observation mainly on general staining methods (haematoxylin and eosin and Mallory's stain) which are less specific than those used in the present study. In fact, the similarity in appearance between the degenerated retinae of the present experiments and those described by Mantz and Klein must be regarded as reflecting both the maturity of the ganglion cell layer at the time of operation and the independence of the differentiation of the other laminae upon the integrity of this layer. 
The problem arises as to the nature of the cells in the ganglion layer which do not degenerate. It is possible that these may be neuroglia, which are easy to mistake for ganglion cells (Polyak, 1941), said by Arey and Gore (1942) to be present in this layer. The evidence suggests, however, that such is not the case. In the first place, the staining reaction with methyl greenpyronin was that characteristic of neurones, the red staining of the cytoplasm indicating the presence of ribonucleic acid. Neuroglia, on the other hand, tend to stain green, which suggests a predominance of more highly polymerized acids in both nucleus and cytoplasm (Kurnick, 1950). White (1950) has shown that the respective affinity of methyl green and pyronin for different nucleic acid polymers depends largely on the method of fixation, so that there is no justification for claiming that this stain alone is capable of distinguishing between neurones and neuroglia. None the less, the presence of appreciable amounts of ribonucleic acid in the cytoplasm, in association with a pale-staining nucleus which contains a prominent nucleolus, strongly suggests that the cells in question are ganglion cells and not supporting elements.

If this be the case, two interdependent questions remain to be answered:

(a) why it is that some neurones degenerate while others persist?

(b) how are the remaining cells related to the optic pathway?

One possibility is that they are internuncial neurones which send no axon to the optic nerve. Such cells have never been recognized histologically however, and, although Zwanenburg (1915) found that the number of ganglion cells exceeded that of the fibres in the optic nerve, the more analytical studies of Arey and Gore (1942) suggest that a 1:1 relationship is more likely. An alternative explanation, and one which would accord well with the experimental observations, is that the surviving cells are those whose main axons travel in the optic nerve but which give off collaterals within the retina. Such cells were described by Marenghi (1900), although their existence has since been discounted by Polyak (1941), who stated that such collaterals " regularly prove to be either other axis cylinders or branchlets of the supporting glial tissue ". Ramón y Cajal (1928), however, described the transformation of cells with long axons into cells with short axons when trauma occurs distal to the site of emergence of collaterals, and it is possible, therefore, that the ganglion cells which survive the degeneration of their main axon have undergone such a transformation. The limitations of the techniques so far employed have precluded a full investigation of this proposition, which is now being studied by more analytical methods.

\section{Summary}

(1) The structural changes which take place in the retina and optic nerve when the latter is crushed in infancy have been studied, using sections stained with van Gieson, cresyl violet, methyl green-pyronin, and reduced silver. 
(2) About 2 months after operation at the age of 5 days the distal portion of the optic nerve had disappeared completely, and the central stump had been invaded by fibrous tissue.

(3) Crushing the optic nerve did not interfere with the differentiation of the retina into its several laminae, but the minute structure of the layers of optic nerve fibres and ganglion cells was changed.

(4) There was a considerable reduction in the number of ganglion cells in the experimental retinae. The cells which remained were mostly small cells with little cytoplasm, and although some larger cells were also present the largest had disappeared altogether. The remaining cells had processes which entered the inner plexiform layer. These cells had the cytological characteristics of ganglion cells and not of neuroglia.

(5) The fasciculi of optic nerve fibres normally located in the innermost layer of the retina has completely disappeared in the experimental tissues. The presence or absence of axons having a short course in this layer could not be determined.

(6) The significance of these findings is discussed in relation to the process of retrograde degeneration and to the relation of the ganglion cells to the fibres comprising the optic nerve.

\section{REFERENCES}

AREY, L. B., and Gore, M. (1942). J. comp. Neurol., 77, 609.

BirCH-HirSCHFELD, A. (1900). v. Graefes Arch. Ophthal., 50, 166.

DeTWILER, S. R. (1932). J. Comp. Neurol., 55, 473.

JAMES, G. R. (1933). Arch. Ophthal., Chicago, 9, 338.

KURNICK, N. B. (1950). J. gen. Physiol., 33, 243.

LeINFELDER, P. J. (1938). Trans. Amer. ophthal. Soc., 36, 307.

MANTZ, J., and KleIN, M. (1951a). C.R. Soc. Biol., Paris, 145, 920. (1951b). Ibid., 145, 922.

Marenghi, G. (1900). Verh. Anat. Ges. Jena., p. 12. (Suppl. to Anat. Anz. 18).

Polyak, S. (1941). “ The Retina ”. Univerisity Press, Chicago.

RAMÓN Y CAJAL, S. (1928). "Degeneration and Regneration of the Nervous System", trans. R. M. May. Oxford University Press, London.

Romanes, G. J. (1950). J. Anat., Lond., 84, 104.

TelLo, F. (1907). Trab. Lab. Invest. biol. Univ. Madr., 5, 237.

WhITE, J. C. (1950). Biochem. J., 46 (Proc.) xxiv.

ZWANENBURG, S. (1915). Inaugural Dissertation. No. 605. Amsterdam. Quoted by Arey and Gore (1942). 